\title{
Food safety and environmental quality impose conflicting demands on Central Coast growers
}

by Melanie Beretti and Diana Stuart

Growers of fresh produce on the Central Coast of California currently face conflicting demands regarding measures to protect food safety and those to protect environmental quality. To explore the extent of conflicting pressures and identify the range of possible impacts on the environment, we conducted a survey of Central Coast irrigated-row-crop growers during spring 2007. The results indicate that growers are experiencing a clear conflict, and some are incurring economic hardships because their practices to protect the environment have resulted in the rejection of crops by buyers. In addition, some growers are being encouraged to or are actively removing conservation practices for water quality, and most growers are taking action to discourage or eliminate wildlife from and adjacent to croplands. These actions could affect large areas of land on the Central Coast and, as indicated by growers, they are likely to increase over time.

he Central Coast of California sup-
ports unique biodiversity and some of the most productive agricultural lands in the United States. The Salinas Valley in Monterey County, often referred to as the "Salad Bowl of America," produces the majority of the nation's lettuce. Since the 1990s, food safety has become increasingly important, especially with respect to outbreaks of E. coli O157:H7 associated with leafy greens: lettuce, escarole, endive, spring mix, spinach, cabbage, kale, arugula and chard (see www. caleafygreens.ca.gov).

Simultaneously, growers on the Central Coast face increasing demands to

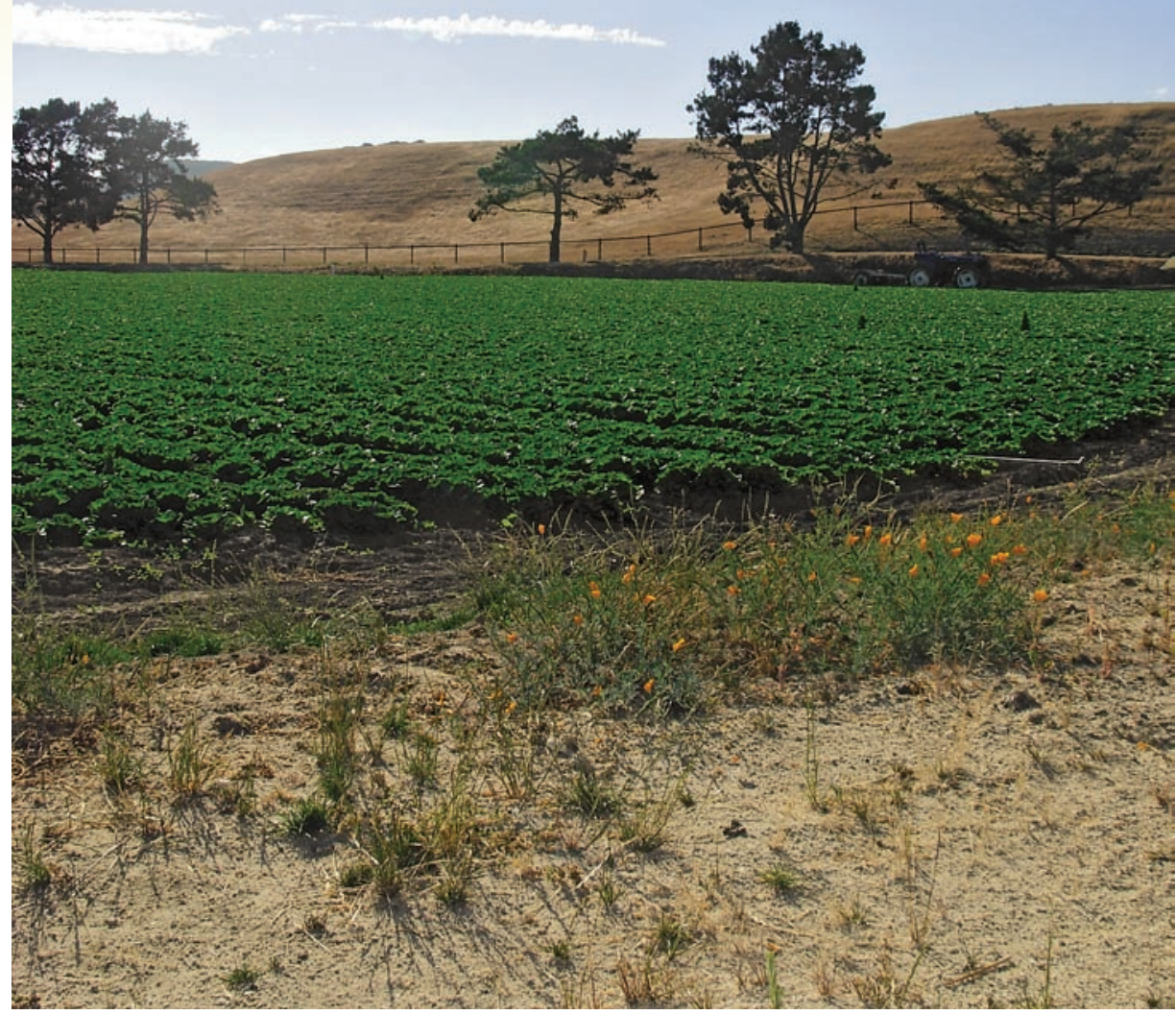

Growers of leafy greens and vegetables must balance the need to improve water quality and wildlife habitat in and around farms, with concerns about food safety.

protect the environment and have taken a proactive approach to improve environmental quality. An important aspect of these efforts is the adoption of conservation practices, which aim to improve and protect water quality, prevent soil erosion, reduce the use of agricultural chemicals and protect wildlife. However, some food safety requirements - or field-level interpretations of these requirements - conflict with management practices intended to improve water quality and enhance natural habitat.

In response to grower concerns over contradictory guidelines and requirements for food safety and environmental protection, the Resource Conservation District (RCD) of Monterey County conducted a mail survey of 600 irrigatedrow-crop growers throughout the Central Coast. The purpose was to better understand the impacts of conflicting demands on growers, and to provide information to aid attempts to reconcile the goals of food safety and environmental protection.

\section{Protecting environmental quality}

The Central Coast contains some of the greatest biodiversity of any temperate region in the world. At its heart is the Monterey Bay National Marine Sanctuary, the largest marine sanctuary in the United States, and the Elkhorn Slough National Estuarine Research Reserve.

While the Central Coast houses many natural resources, according to the Central Coast Regional Water Quality Control Board (CCRWQCB), it also has some of the most polluted waters in California. The Pajaro River and Elkhorn Slough are listed as impaired for sediment and nutrients under California's 2002 Section 303(d) of the 1972 Clean Water Act. The Salinas River is 303(d)-listed as impaired for sediment, nutrients, pesticides and pathogens. In 2003, the 20-year-old state Agricultural Waiver of Nonpoint Source Discharge ended, meaning that growers are no longer exempt from water qual- 


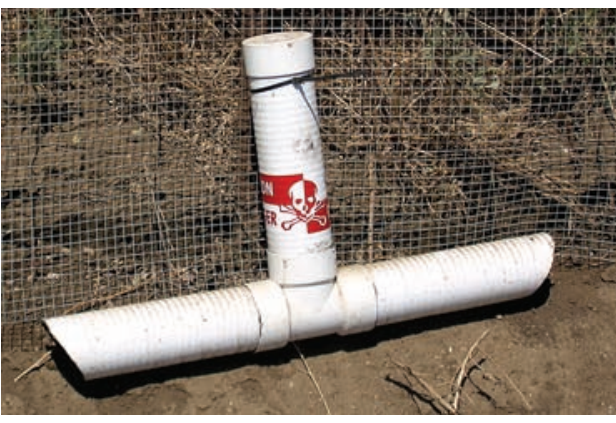

ity laws. In response, the CCRWQCB adopted a Conditional Waiver Program in 2005, which requires growers to enroll in the program, attend waterquality training sessions, adopt farm water-quality management plans, complete management practice checklists and participate in water quality monitoring (Cal EPA 2007).

An important aspect of these efforts is the adoption of conservation practices, which aim to improve and protect water quality, prevent soil erosion, reduce the use of agricultural chemicals and protect wildlife. Vegetation on and around farmland is a key component, including vegetated field borders, grassed waterways, riparian buffers and constructed wetlands. For the past decade, the Central Coast farming community has been proactively working with resource agencies to develop and implement voluntary conservation practices to improve water quality and reduce water consumption through the adoption and implementation of the Monterey Bay National Marine Sanctuary's Agricultural and Rural Lands Plan (MBNMS 1999). Adoption of these practices has now become a key component for compliance with the CCRWQCB's Conditional Waiver Program.

\section{Protecting food safety}

Since the late 1990s, government agencies, researchers and the produce industry have worked to develop and implement voluntary guidelines, or Good Agricultural Practices, to minimize the risk of food contamination (FDA 1998; Bihn 2004). These practices aim to protect consumer health at all levels of leafy greens production and distribution, and they have become increasingly important in light of recent outbreaks. The September 2006 outbreak of E. coli O157:H7 associated with bagged spinach from the Central Coast resulted in the loss of three lives and caused more than 200 illnesses.

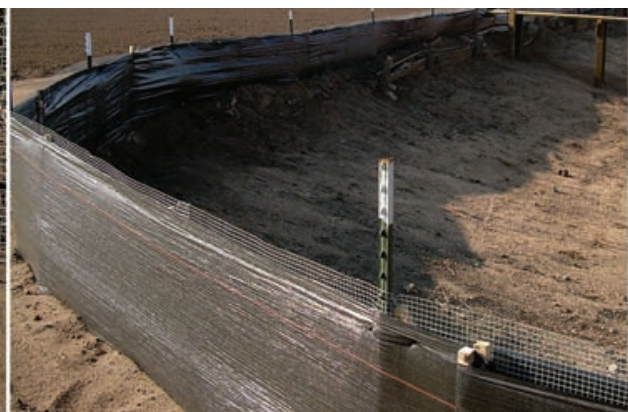

This outbreak affected consumers in 26 states, drawing national attention (CDC 2006) and acting as a catalyst for rapid change in food safety protection efforts for leafy greens. Despite an intensive investigation, the U.S. Food and Drug Administration (FDA) and the California Department of Health Services (CDHS) have not been able to conclusively determine the specific causes of the spinach outbreak (CDHS/ FDA 2007).

In early 2007, with oversight by the California Department of Food and Agriculture (CDFA), produce industry representatives developed the California Leafy Green Products Handler Marketing Agreement (see www.caleafygreens.ca.gov). More than 100 handlers (companies that move fresh produce products from growers to retail and food-service buyers) are signatories. Representing more than 99\% of the leafy greens production in California, they are obligated to handle leafy green produce only from growers who adhere to the best management practices detailed in the Commodity Specific Food Safety Guidelines for the Production and Harvest of Lettuce and Leafy Greens, known as the "Metrics" (see www.caleafygreens.ca.gov). The Metrics were developed and continue to be updated through a process involving the produce industry, government agencies, natural resource organizations and scientists.

In addition to the Metrics, many companies and retailers who handle or sell leafy greens have developed their own company-specific food safety requirements, which also affect farm management practices. Because growers often sell their crops to multiple buyers, most now must meet at least one if not several different sets of requirements. In addition, field interpretations of the Metrics and company-specific guidelines vary. Depending on the size and type of operation, a grower may conduct self-audits

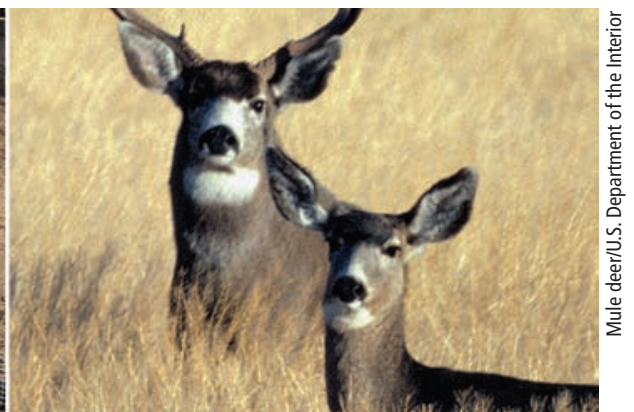

Left, a poison bait trap and fence to keep small animals out of fields; center, a small mammal/ amphibian exclusion fence constructed around a tail-water recovery pond; right, mule deer. In the survey, a Central Coast grower could not sell $\$ 17,500$ worth of crops because a food safety audit found deer tracks near the field.

as well as undergo food safety inspections and audits by the CDFA, processors, grower-shippers or third-party auditors representing the companies that purchase their products.

Specific measures stated or implied in the Metrics and company-specific requirements may potentially conflict with efforts to improve and protect water quality and support wildlife habitat. For example, the Metrics identify "animals of significant risk" for contaminating crops and provide remediation guidelines. Measures to deter animals and comply with food safety requirements, such as fencing and bare-ground buffers around fields, can also result in adverse impacts to the environment. This may include the alteration or elimination of wildlife habitat, including the removal of surrounding vegetation. Noncrop vegetation is a key component of conservation practices such as field borders, grassed waterways and riparian buffers. Because vegetation provides water filtration and absorption, and reduces the deposition of sediment and pollutants into waterways, widespread vegetation removal could have significant environmental impacts.

\section{Mail survey to row-crop growers}

The Monterey County RCD conducted a mail survey in spring 2007, which was co-sponsored by the Grower-Shipper Association of Central California, the Central Coast Agriculture Water Quality Coalition and the Monterey County Agricultural Commissioner's office. The survey packet and cover letter were mailed to 


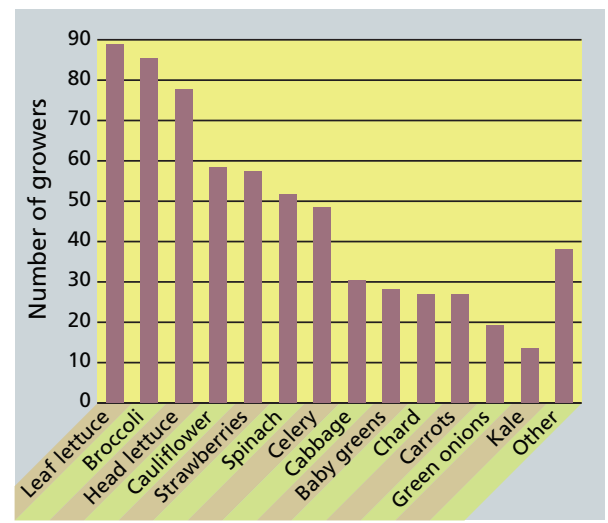

Fig. 1. Number of respondents who grow each commodity; most grow more than one crop.

\begin{tabular}{|c|c|}
\hline Conservation practice & Respondents \\
\hline & $\%$ \\
\hline Cover crop & 72.1 \\
\hline Stormwater pond & 38.5 \\
\hline Filter strip & 36.3 \\
\hline Grassed waterway & 33.5 \\
\hline Irrigation reservoir & 30.2 \\
\hline Tailwater recovery pond & 29.6 \\
\hline Hedgerow & 25.7 \\
\hline Riparian restoration & 18.4 \\
\hline Constructed wetland & 6.1 \\
\hline Other & 3.9 \\
\hline
\end{tabular}

all 600 row-crop operations listed on the CCRWQCB Conditional Waiver Program's mailing list. These growers had operations in Monterey, San Benito, Santa Barbara, Santa Clara, Santa Cruz and/or San Luis Obispo counties. Three weeks following the initial mailing, a reminder postcard was sent to the entire mailing list.

The four-page survey contained 39 questions, consisting of multiple choice, yes/no, five-point Likert-scale and open-ended questions. Questions included details on farm operations, participation in conservation programs, the adoption of conservation practices, specifics about food safety requirements, information on how respondents are changing or have changed their practices, and opinionoriented questions to allow respondents to make comments and voice concerns.

The survey also asked respondents about the circumstances under which they have had crops rejected by buyers and auditors due to food safety concerns as well as the economic impacts of these rejections. Growers were asked a series of questions related to food safety, and practices to protect water quality and the environment. The survey sought responses on three main categories of practices and/or natural features: (1) noncrop vegetation, (2) ponds or waterways and (3) wildlife.

Analysis of the results included descriptive statistics as well as the comparison of data between different groups of respondents. We looked at differences between respondents who indicated that they grow leafy greens and those who grow other crops. In addition, we explored how other characteristics such as operation size and type (conventional or organic) affect management decisions. We used the Pearson Chi Square statistic to test for significance.

\section{Food safety vs. water quality}

A total of 181 growers returned surveys, for a 30\% response rate. Almost all respondents indicated that they grow more than one crop, primarily leaf lettuce, broccoli, head lettuce, cauliflower, strawberries, spinach, celery, cabbage and baby greens (fig. 1). Approximately $86 \%$ grow conventional only or both conventional and organic, whereas $13 \%$ were organic only.

More than $80 \%$ of the respondents met education requirements of the Conditional Waiver Program through attendance at the Farm Water Quality Planning Short Course and had completed Farm Water Quality Plans.

Ninety-one percent (91.1\%) had adopted one or more conservation practices

\begin{tabular}{|c|c|}
\hline Question & $\begin{array}{l}\text { Affirmative } \\
\text { responses }\end{array}$ \\
\hline & $\%$ \\
\hline $\begin{array}{l}\text { "It has been suggested that I should } \\
\text { remove noncrop vegetation" }\end{array}$ & 18.6 \\
\hline $\begin{array}{l}\text { "I have lost points on audit reports } \\
\text { because of noncrop vegetation" }\end{array}$ & 9.6 \\
\hline $\begin{array}{l}\text { "It has been suggested that I should } \\
\text { remove ponds or waterbodies" }\end{array}$ & 9.5 \\
\hline $\begin{array}{l}\text { "I have lost points on audit reports } \\
\text { because of ponds or waterbodies" }\end{array}$ & 10.8 \\
\hline $\begin{array}{l}\text { "It has been suggested that I should } \\
\text { remove wildlife" }\end{array}$ & 39.0 \\
\hline $\begin{array}{l}\text { "I have lost points on audit reports } \\
\text { because of wildlife" }\end{array}$ & 13.0 \\
\hline
\end{tabular}

aimed to improve water quality and/ or wildlife habitat. Sixty-three percent $(62.8 \%)$ had received technical assistance for water quality or habitat improvement projects from a local resource agency or expert such as the RCD or USDA Natural Resources Conservation Service. Cover cropping was the most common practice adopted by respondents $(72.1 \%)$ (table 1 ).

Crop rejection. Eight percent (8.0\%) of growers reported that their crops had been rejected based on the presence of practices to improve water quality or wildlife habitat on the farm. Some of the explanations shared by respondents included:

- Lost $\$ 17,500$ worth of crop due to deer tracks.

- 1 acre of romaine lettuce rejected due to proximity to horse pen.

- 23 acres of head lettuce and 2 acres of mixed lettuce rejected due to contact with Salinas River floodwater.

- Crop rejected due to potential frog habitat.

- Portions of fields rejected by processor if frogs, tadpoles, snails, mice or other small animals were found.

- Harvest stopped due to the presence of frogs and tadpoles in creek.

- Crop rejected due to deer intrusion.

- Crops planted for processor near trees needed a buffer of 100 to 150 feet.

In some cases crops were not rejected outright; however, growers responded that their buyers, auditors or others had suggested either discouraging or eliminating noncrop vegetation, water bodies and wildlife in and around fields. Growers reported they had lost points on food safety audits due to the presence of noncrop vegetation $(9.6 \%$ of respondents), water bodies (10.8\%) and wildlife $(13 \%)$ near their crops (table 2). Growers also indicated that in some cases they acted in response to buyer/auditor suggestions and actively removed these features or adopted mitigation measures accepted by their auditors or buyers. In all three categories (noncrop vegetation, water bodies and wildlife), growers of leafy greens were more likely to have been told to discourage or eliminate these features than growers of other crops. In two of the three categories (noncrop vegetation and wildlife) leafy greens growers were 


\begin{tabular}{|c|c|c|}
\hline \multicolumn{3}{|c|}{$\begin{array}{l}\text { TABLE 3: Comparison of affirmative responses by } \\
\text { leafy green versus nonleafy green growers } \\
(n=181) \text { to questions concerning the removal } \\
\text { of conservation practices or natural features } \\
\text { in or adjacent to cropland }\end{array}$} \\
\hline \multirow[b]{2}{*}{ Question } & \multicolumn{2}{|c|}{ Growers of } \\
\hline & $\begin{array}{c}\text { Leafy } \\
\text { greens }\end{array}$ & $\begin{array}{c}\text { Nonleafy } \\
\text { greens }\end{array}$ \\
\hline & \multicolumn{2}{|c|}{$\ldots \ldots \ldots \% \ldots$} \\
\hline $\begin{array}{l}\text { "It has been suggested } \\
\text { that I should remove } \\
\text { noncrop vegetation" }\end{array}$ & 32.1 * & 2.8 \\
\hline $\begin{array}{l}\text { "I have actively removed } \\
\text { noncrop vegetation in } \\
\text { response to comments by } \\
\text { auditors or others" }\end{array}$ & 32.1 * & 6.9 \\
\hline $\begin{array}{l}\text { "It has been suggested } \\
\text { that I should remove } \\
\text { ponds or water bodies" }\end{array}$ & $14.8^{*}$ & 3.0 \\
\hline $\begin{array}{l}\text { "I have actively removed } \\
\text { ponds or water bodies in } \\
\text { response to comments by } \\
\text { auditors or others" }\end{array}$ & 7.4 & 6.0 \\
\hline $\begin{array}{l}\text { "It has been suggested } \\
\text { that I should remove } \\
\text { wildlife" }\end{array}$ & $47.7 \dagger$ & 27.9 \\
\hline $\begin{array}{l}\text { "I have actively removed } \\
\text { wildlife in response to } \\
\text { comments by auditors or } \\
\text { others" }\end{array}$ & $40.7^{*}$ & 23.5 \\
\hline $\begin{array}{l}* P<0.05 \\
+P<0.10 .\end{array}$ & & \\
\hline
\end{tabular}

significantly $(P<0.05)$ more likely than growers of other crops to have acted on these suggestions (table 3).

Conservation practice abandonment. Approximately 15\% of all growers surveyed indicated that they had removed or discontinued the use of previously adopted conservation practices in response to suggestions made by auditors or buyers due to food safety concerns. Growers of leafy greens were significantly $(P<0.05)$ more likely to have taken out conservation practices than other growers: $21.1 \%$ indicated that they had actively taken out one or more conservation practices due to food safety concerns, as compared to $7.4 \%$ that grow nonleafy green crops.

Practices that had been removed or were planned for removal included: (1) ponds and/or reservoirs (such as irrigation reservoirs, duck habitat and ponds); (2) irrigation reuse systems (such as tail-water recovery ponds and water reuse); and (3) noncrop vegetation (such as grassed waterways, filter/buffer strips and trees/shrubs). In addition, some growers stated that although they had not yet removed conservation practices, they were planning to or felt they

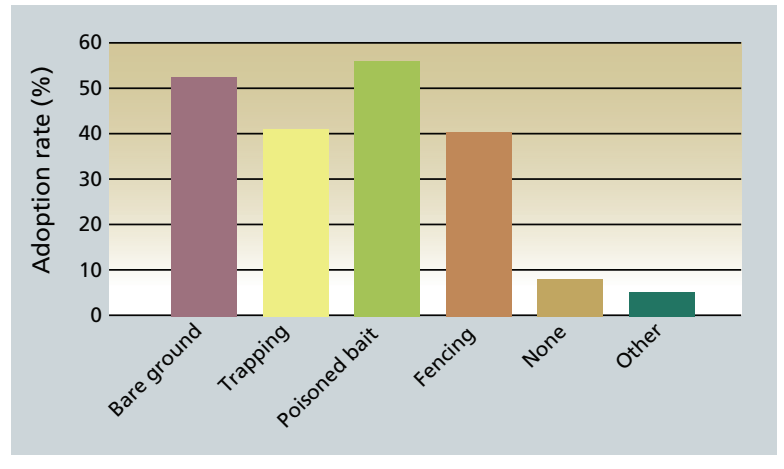

Fig. 2. Percentage of respondents who indicated they have adopted specific mitigation measures for wildlife.

would be required to in the near future. Several respondents suggested that a follow-up survey would reveal more changes being made.

Wildlife exclusion. Some $88.9 \%$ of the survey respondents indicated that they had adopted at least one measure to actively discourage or eliminate wildlife from cropped areas (fig. 2). The most commonly adopted measures were: bare-ground buffers, fencing, trapping and poisoned bait stations. Bare-ground buffers and poisoned bait stations were each used by more than half of the respondents to protect crops from wildlife intrusion. Trapping and fencing were each used by approximately $40 \%$. Growers of leafy greens were significantly more likely to be using bare-ground buffers $(P<0.05)$, poisoned bait stations $(P<0.05)$ and traps $(P<0.01)$.

Growers most affected. Results from the survey suggest that the conflict between food safety and environmental protection disproportionately affects respondents who sell to shippers and packers, operate on more than 500 acres and grow conventionally (as opposed to organic only). Of respondents who had removed conservation practices, $87.8 \%$ sell to shippers and packers, whereas only $67 \%$ of all respondents sold to shippers and packers. Of respondents who had removed conservation practices $89 \%$ operate more than 500 harvested acres, whereas only $39 \%$ of all respondents operated more than 500 harvested acres.

In addition, large farm operators (> 500 acres) were significantly $(P<0.05)$ more likely to have been told to eliminate wildlife and waterways and significantly more likely to have adopted mitigation measures. Of the respondents who had removed conservation practices, $100 \%$ grew conventionally (conventional, and conventional and organic operations), whereas $86 \%$ of all respondents grew conventionally.

Acreage affected. The growers who responded to the survey manage more than 140,000 acres of row-crop land on the Central Coast. Of these, those who had actively removed conservation practices for water quality or wildlife habitat (in response to suggestions by food safety auditors or others) manage nearly 30,000 acres. In addition, respondents who had adopted measures to actively deter or eliminate wildlife manage more than 133,000 acres. Survey respondents that use bare-ground buffers manage 91,890 acres (65\% of the total land reported); trapping manage 87,279 acres $(62 \%)$; poisoned bait stations manage 108,283 acres (77\%); and fencing manage 66,380 acres $(47 \%)$.

Grower comments. More than $30 \%$ of all respondents also chose to share their personal opinions and concerns at the end of the survey. These comments indicated that many growers face serious pressure regarding food safety, and they are concerned about doing things that may have negative impacts on the environment. Their responses suggested that in many cases growers have little choice in their management practices and must be responsive to buyers' and auditors' suggestions in order to sell their crops. For example, one grower wrote: "I am afraid many positive environmental programs and practices are going to be abandoned due to retailers'/shippers' new food safety practices. I am all for the environment and safe food, but feel many new food safety ideas are being driven by fear and uncertainty rather than sound science."

And another wrote: "Our experience has been that the food safety auditors have been very strict about any vegetation that might provide habitat. We are very concerned about upsetting the 
natural balance, but we have to comply with our shipper's requests."

\section{Conflict on the Central Coast}

The survey results illustrate that growers are in the middle of a clear conflict between current food safety standards and continued efforts to address water quality and environmental concerns on the Central Coast. It appears that growers of leafy greens who operate larger acreages are especially affected by food safety concerns; however, other growers are also affected to a lesser extent. Growers are incurring economic hardships due to the rejection of crops based on the presence of practices to protect the environment. Some growers are encouraged to or are actively removing conservation practices in response to food safety audits and concerns. Many growers are taking action to discourage or eliminate wildlife and habitat, natural lands, hedgerows and windbreaks. Discouraging or actively removing these features will have negative environmental impacts and, in some cases, could actually increase the risk of crop contamination (Stuart 2006; Stuart et al. 2006).

For example, contamination in overland water flows may be reduced by filtration through perennial forage or grasses (Tate et al. 2006). Vegetated treatment systems (such as grassed waterways and vegetated basins) have also been shown to reduce the presence and transport of pathogens (Kadlec and Knight 1996; Koelsch et al. 2006). Lastly, constructed wetlands have been found to effectively remove pathogens in water through filtration in dense vegetation, sedimentation, microbial competition and predation, high temperatures, and UV disinfection (Hench et al. 2003; Nokes et al. 2003; Greenway

\section{Growers are concerned about being put in the unfair position of choosing between being able sell their crops or protecting the environment.}

other noncrop vegetation. These actions could have impacts over large areas of land in the region. In addition, comments from growers indicated that these actions are likely to increase over time as food safety standards become more established. The survey also indicated that growers are concerned about being put in the unfair position of choosing between being able to sell their crops or protecting the environment.

Protecting human health and insuring the viability and sustainability of California agriculture demands safe food, clean water and biodiversity. However, the virulence of E. coli O157:H7 coupled with the consumption of raw leafy greens poses an unprecedented challenge to the produce industry. Our survey results indicate that current practices to address food safety in the field may result in environmental concessions including habitat loss, degradation and continued water-quality impairment. The removal of noncrop vegetation, for example, can include common conservation practices such as filter or buffer strips, grassed waterways, riparian et al. 2005). Given the results of these studies, further evaluation of food safety standards requiring the removal of vegetation may be necessary.

Scientific uncertainty plays a significant role in the current conflict, particularly regarding animal sources of E. coli O157:H7. Although studies agree that cattle (Hancock et al. 1998; Chapman et al. 1997) and some commensal wildlife species (associated with humans) are known sources of E. coli O157:H7 (Fenlon 1981; Meerburg et al. 2004), most studies on pastoral wildlife (associated with natural environments) do not illustrate a substantial threat to food safety. Studies looking at pastoral small mammals and deer showed minimal prevalence of E. coli O157:H7 (Hancock et al. 1998; Sargeant et al. 1999; Fischer et al. 2001). Studies also indicate that there is a very low probability $(0-1 \%)$ that birds associated with natural environments will carry pathogenic bacteria that could contaminate food crops (Brittingham et al. 1988; Hancock et al. 1998). More recently, E. coli O157:H7 was isolated in feral swine near spinach fields and cattle on the Central Coast following the 2006 spinach outbreak (Jay et al. 2007). Deer and geese residing in high densities in watersheds heavily populated by humans and dairies have been identified as sources of E. coli O157:H7 in New York state (Somarelli et al. 2007). Despite these studies, there is still much uncertainty regarding the role of wildlife specific to the Central Coast region.

New scientific studies are already under way to investigate the role of wildlife and vegetation in food safety, as well as other sources and vectors of E. coli O157:H7 on the Central Coast. Although new studies will improve our understanding of risks to food safety, they will not be able to provide $100 \%$ certainty or eliminate all possible sources of contamination. Therefore, it becomes essential to weigh relative risks and focus attention and resources on the most likely sources of contamination. How current and future standards affect the risk of contamination should be evaluated. For example, conservation practices that have been shown to reduce the presence and transport of human pathogens could be an asset in meeting food safety goals. Keeping produce as safe as possible is a critical goal; however, the means to achieve this goal should be carefully investigated to insure those measures actually reduce risks of crop contamination, do not increase other human health risks as a result of environmental degradation, and are costeffective and practical to implement.

This survey was conducted during the spring of the first growing season following the development and adoption of the California Leafy Green Products Handler Marketing Agreement. Because food safety pressures have continued to intensify - with a proliferation of food safety guidelines and increased field audits - our results likely present a conservative estimate of the on-the-ground impacts of this conflict. As standards and measures are developed to protect food safety, government and industry leaders should be conscious of how these measures affect growers as well as the environment. 
The process and standards for protecting food safety in leafy greens on the Central Coast of California set a precedent that will certainly be modeled for other crops and growing regions nationwide. As of January 2008, efforts were being put forth to develop a Federal Marketing Agreement and provide the foundation for a Federal Marketing Order for leafy greens. In addition, private industry and companies that buy fresh produce continue to develop mandatory field-level food safety requirements that go beyond the currently adopted Metrics.

Based on the survey results - and ongoing efforts of the agricultural community and local, state and national organizations - there is a clear need to alleviate conflicting pressures facing growers. Resolving this conflict will require an open dialogue between scientists, environmental and food safety organizations, and leaders in the produce industry to create management standards that support both food safety and environmental stewardship. We have the opportunity and responsibility to learn from this conflict on the Central Coast, and insure that our agricultural and natural resources are successfully co-managed for human and environmental health.

M. Beretti is Program Director, Resource Conservation District of Monterey County, Salinas; and D. Stuart is Doctoral Candidate, Department of Environmental Studies, UC Santa Cruz.

Thanks to our co-sponsors: the Monterey County Agricultural Commissioner's Office, GrowerShipper Association of Central California and Central Coast Agricultural Water Quality Coalition. Additional thanks to: Rene Aguas, Jo Ann Baumgartner, Jim Bogart, Jennifer Clark, Sam Earnshaw, April England, Jeane Errea, Margaret FitzSimmons, Chris Goodson, Lea Haratani, Dina Iden, Robert LaFleur, Eric Lauritzen, Jessica Lee, Bob Martin, Dawn Mathes, Laura G. Mills, Deborah Nares, Joe Pezzini, Carol Presley, Daniel Press, Bob Roach, Traci Roberts, Rami Shihadeh, Kathy Thomasberg, the USDA Natural Resource Conservation Service and the Region 3 Water Quality Control Board.

This study was funded in part by the Community Foundation for Monterey County (\#20040679), the California State Water Resources Control Board (\#04-326-553-0 and 05-122-553-1) and USDA Natural Resources Conservation Service (\#65-9104-7-611).

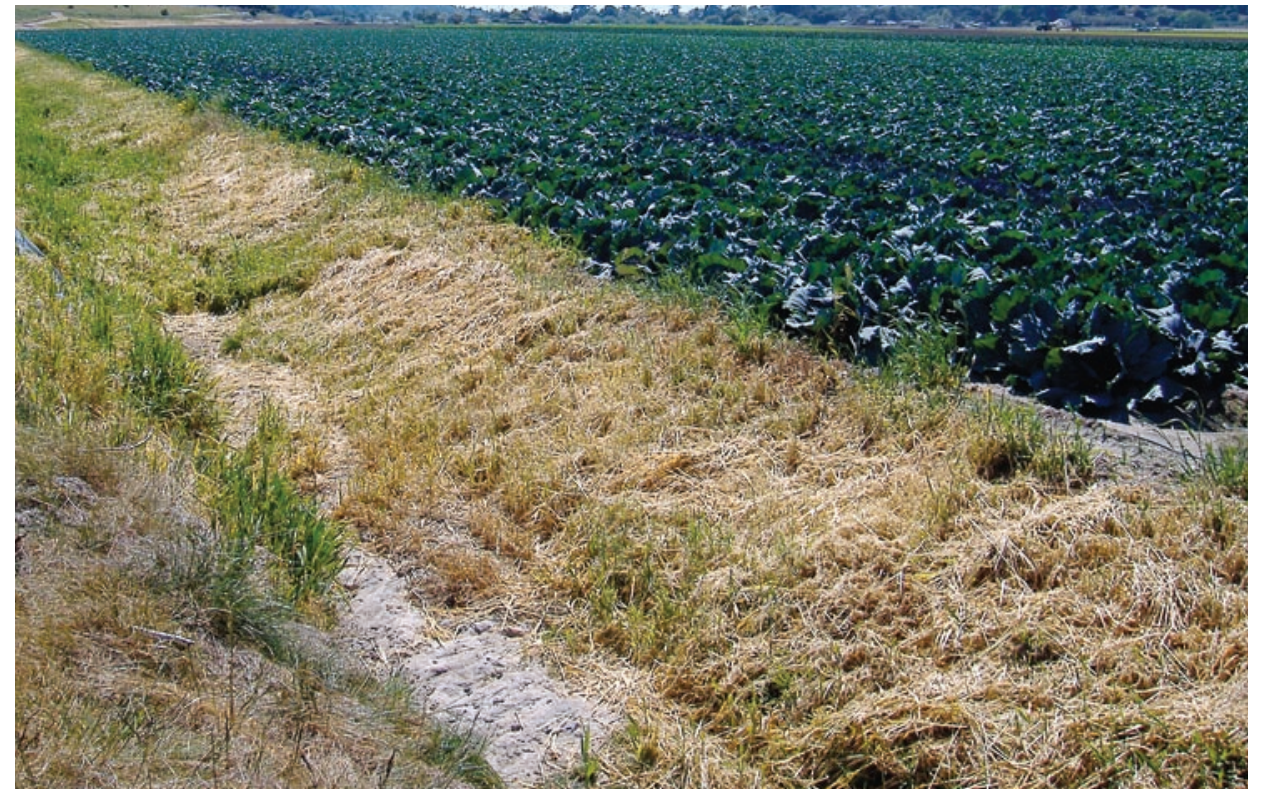

Border strips around fields, shown on a Central Coast farm, help improve water quality by filtering runoff into and off of farmland. However, such strips may also create habitat for small animals, which may be perceived as a food safety risk.

\section{References}

Bihn EA. 2004. Food Safety Begins on the Farm: Reduce Microbial Contamination with Good Agricultural Practices. Cornell University, Department of Horticulture. 2 p. www.gaps.cornell.edu/Educationalmaterials/ Samples/PamphletEng.pdf.

Brittingham MC, Temple SA, Duncan RM. 1988. A survey of the prevalence of selected bacteria in wild birds. J Wildlife Dis 24(2):299-307.

[Cal EPA] California Environmental Protection Agency. 2007. Water Quality: Irrigated Agricultural Waivers Program. State Water Resources Control Board. wuw.waterboards.ca.gov/agwaivers (accessed Feb. 15, 2008).

[CDC] Centers for Disease Control and Prevention. 2006. Multistate outbreak of E. coli O157 infections, November-December 2006. www.cdc.gov/ecoli/2006/ december/121406.htm (accessed June 15, 2007).

[CDHS/FDA] California Department of Health Services and US Food and Drug Administration. 2007 Investigation of an Escherichia coli 0157:H7 Outbreak Associated with Dole Pre-Packaged Spinach. Sacramento CA. www.DHS.ca.gov.

Chapman PA, Siddons CA, Malo ATC, Harkin MA 1997. A 1-year study of Escherichia coli 0157 in cattle sheep, pigs and poultry. Epidemiol Infect 119(2):245-50.

[FDA] US Food and Drug Administration. 1998. Guidance for Industry: Guide to Minimize Microbial Food Safety Hazards for Fresh Fruits and Vegetables. Center for Food Safety and Applied Nutrition. Washington, DC www.cfsan.fda.gov/ dms/prodguid.html.

Fenlon DR. 1981. Seagulls (Larus spp) as vectors of Salmonellae: An investigation into the range of serotypes and numbers of Salmonellae in gull feces.

J Hygiene 86(2):195-202.

Fischer JR, Zhao T, Doyle MP, et al. 2001. Experimental and field studies of Escherichia coli 0157:H7 in white-tailed deer. Appl Env Microbiol 67(3):1218-24.

Greenway M. 2005. The role of constructed wetlands in secondary effluent treatment and water reuse in subtropical and Australia. Ecol Engin 25(5):501-9.

Hancock DD, Besser TE, Rice DH, et al. 1998. Multiple sources of Escherichia coli 0157 in feedlots and dairy farms in the northwestern USA. Prevent Vet Med 35(1):11-9.

Hench KR, Bissonnette GK, Sexstone AJ, et al. 2003. Fate of physical, chemical, and microbial contaminants in domestic wastewater following treatment by small constructed wetlands. Water Res 37(4):921-7.

Jay MT, Cooley M, Carychao D, et al. 2007. Escherichia coli 0157:H7 in feral swine near spinach fields and cattle, central coast. Emerg Infectious Dis 13(12):1908-11.

Kadlec RH, Knight RL. 1996. Treatment Wetlands. Boston: Lewis. 893 p.

Koelsch RK, Lorimor JC, Mankin KR. 2006. Vegetative treatment systems for management of open lot runoff: Review of literature. Appl Eng Agric 22(1):141-53.

[MBNMS] Monterey Bay National Marine Sanctuary. 1999. Water Quality Protection Program. Action Plan IV: Agriculture and Rural Lands. Monterey, CA. http://montereybay.noaa.gov/resourcepro/reports/ agactioniv_99/ag99_about.html.

Meerburg BG, Bonde M, Brom FWA, et al. 2004. Towards sustainable management of rodents in organic animal husbandry. Njas-Wageningen J Life Sci 52(2):195-205

Nokes RL, Gerba CP, Karpisak MM. 2003. Microbial water quality improvement by small scale on-site subsurface wetland treatment. J Env Sci Health Part A-Toxic/Hazardous Substances and Env Eng 38(9):1849-55.

Sargeant JM, Hafer DJ, Gillespie JR, et al. 1999. Prevalence of Escherichia coli 0157:H7 in white-tailed deer sharing rangeland with cattle. J Am Vet Med Assoc 215(6):792-4.

Somarelli JA, Makarewicz JC, Sia R, Simon R. 2007. Wildlife identified as major source of Escherichia coli in agriculturally dominated watershed by BOX A1Rderived genetic fingerprints. J Env Manage 82:60-5.

Stuart DL. 2006. Reconciling Food Safety and Environmental Protection: A Literature Review (1st Ed.). Resource Conservation District of Monterey County. Salinas, CA. www.rcdmonterey.org.

Stuart D, Shennan C, Brown M. 2006. Food Safety versus Environmental Protection on the Central California Coast: Exploring the Science Behind the Apparent Conflict. UC Santa Cruz, Center for Agroecology and Sustainable Food Systems. Res Brf \#10. http://casfs. ucsc.edu/publications/briefs/index.html.

Tate KW, Atwill ER, Bartolome JW, Nader G. 2006 Significant Escherichia coli attenuation by vegetative buffers on annual grasslands. J Env Qual 35:795-805. 